\title{
Apolipoprotein E Markedly Facilitates Age-Dependent Cerebral Amyloid Angiopathy and Spontaneous Hemorrhage in Amyloid Precursor Protein Transgenic Mice
}

\author{
John D. Fryer, ${ }^{1}$ Jennie W. Taylor, ${ }^{1}$ Ronald B. DeMattos, ${ }^{4}$ Kelly R. Bales, ${ }^{4}$ Steven M. Paul, ${ }^{4,5}$ Maia Parsadanian, ${ }^{1}$ and \\ David M. Holtzman ${ }^{1,2,3}$ \\ Departments of ${ }^{1}$ Neurology and ${ }^{2}$ Molecular Biology and Pharmacology and the ${ }^{3}$ Center for the Study of Nervous System Injury, Washington University \\ School of Medicine, St. Louis, Missouri 63110, ${ }^{4}$ Neuroscience Discovery Research, Eli Lilly and Company, Lilly Research Laboratories, Indianapolis, Indiana \\ 46285, and ${ }^{5}$ Departments of Pharmacology, Toxicology, and Psychiatry, Indiana University School of Medicine, Indianapolis, Indiana 46285
}

Cerebral amyloid angiopathy (CAA) is a common cause of brain hemorrhage in the elderly. It is found in the majority of patients with Alzheimer's disease (AD). The most common form of CAA is characterized by the deposition of the amyloid- $\beta(\mathrm{A} \beta)$ peptide in the walls of cerebral vessels, and this deposition can lead to hemorrhage and infarction. As in $\mathrm{AD}$, the $\epsilon 4$ allele of apolipoprotein $\mathrm{E}(\mathrm{APOE})$ is a risk factor for CAA. To determine the effect of apoE on CAA and associated hemorrhage in vivo, we used two amyloid precursor protein (APP) transgenic mouse models that develop age-dependent $\mathrm{A} \beta$ deposition: PDAPP and APPsw mice. We found that both models developed an age-dependent increase in CAA and associated microhemorrhage, with the APPsw model having an earlier and more severe phenotype; however, when APPsw and PDAPP mice were bred onto an Apoe-1- background, no CAA was detected through 24 months of age, and there was little to no evidence of microhemorrhage. Biochemical analysis of isolated cerebral vessels from both PDAPP and APPsw mice with CAA revealed that, as in human CAA, the ratio of $\mathrm{A} \beta$ 40:42 was elevated relative to brain parenchyma. In contrast, the ratio of $A \beta$ 40:42 from cerebral vessels isolated from old PDAPP, Apoe-I- mice was extremely low. These findings demonstrate that murine apoE markedly promotes the formation of CAA and associated vessel damage and that the effect of apoE combined with the level of $\mathrm{A} \beta_{40}$ or the ratio of $\mathrm{A} \beta 40: 42$ facilitates this process.

Key words: Alzheimer's disease; apolipoprotein E; cerebral amyloid angiopathy; amyloid $\beta$; ratio; hemorrhage; transgenic models

\section{Introduction}

Cerebral amyloid angiopathy (CAA) consists of deposition of amyloid in brain arterioles, capillaries, and leptomeningeal vessels. The most common form of CAA results from deposition of the amyloid- $\beta$ (A $\beta)$ peptide in the walls of cerebral vessels, gradually replacing the smooth muscle cell layer (Vinters, 1987). The vast majority of patients diagnosed with Alzheimer's disease (AD) also have CAA. A major consequence of CAA is fatal lobar cerebral hemorrhage, and it also appears to play a role in ischemic brain lesions and leukoariaosis (Greenberg, 1998; Revesz et al., 2002).

The $\mathrm{A} \beta$ peptide is $38-43$ amino acids in length and is derived from proteolytic processing of a longer precursor protein termed the amyloid- $\beta$ precursor protein (APP). The predominant $\mathrm{A} \beta$ peptide present in CAA is $\mathrm{A} \beta_{40}$, whereas in brain parenchymal plaques it is $\mathrm{A} \beta_{42}$ (Joachim et al., 1988; Prelli et al., 1988; Suzuki et al., 1994; Alonzo et al., 1998; McCarron et al., 2000). Several

\footnotetext{
Received April 22, 2003; revised July 9, 2003; accepted July 10, 2003.

This work was supported by National Institutes of Health Grants AG13956, AG05681, AG11355, and NS034467. Special thanks to Malca Kierson, Robert Brendza, and Margaret Racke for technical support.

Correspondence should be addressed to Dr. David M. Holtzman, Washington University School of Medicine, Department of Neurology, 660 South Euclid Avenue, Box 8111, St. Louis, M0 63110. E-mail: holtzman@neuro.wustl.edu.

Copyright $\odot 2003$ Society for Neuroscience $\quad$ 0270-6474/03/237889-08\$15.00/0
}

transgenic mice have been created using APP constructs containing familial $\mathrm{AD}$ mutations that recapitulate many aspects of the amyloid-related pathology of AD (Hock and Lamb, 2001). Many of these models have been shown to have both diffuse and neuritic plaques in brain parenchyma, and a few have been shown to develop CAA (Calhoun et al., 1999; Holtzman et al., 2000a; Van Dorpe et al., 2000).

The role of apolipoprotein E (apoE) in the genetics and pathogenesis of AD has been well established (Strittmatter and Roses, 1995; Wisniewski et al., 1997). As with AD, the $\epsilon 4$ allele of APOE is a risk factor for developing CAA (Schmechel et al., 1993; Greenberg et al., 1995; Nicoll et al., 1997), whereas the $\epsilon 2$ allele is a risk factor for developing hemorrhage associated with CAA (Nicoll et al., 1996, 1997; Greenberg et al., 1998). Previous studies using APP transgenic mouse models of AD (in particular the PDAPP mouse) have shown that the absence of murine apoE does not result in a delay in the onset of $A \beta$ deposition (Holtzman et al., 1999), but it does result in a decrease in the level of $A \beta$ deposition and a marked delay in the onset of fibrillar $\mathrm{A} \beta$ deposits (amyloid) (Bales et al., 1997) as well as CAA up to 12 months of age (Holtzman et al., 2000a).

To date, the effects of apoE on CAA and its consequences have not been well studied. Herein, we examine the extent and effects of apoE on CAA in both APPsw (Tg2576) and PDAPP mice 
through 24 months of age, two different transgenic models with $\mathrm{AD}$ pathology. We found that CAA occurs earlier and to a much greater extent in APPsw than PDAPP mice but that both develop CAA-associated microhemorrhages. In the absence of apoE, however, CAA and CAA-associated microhemorrhages are markedly reduced even when assessed at a very old age. Finally, as in human CAA, the ratio of $\mathrm{A} \beta$ 40:42 is elevated relative to brain parenchyma and also reduced in the absence of apoE. Our findings demonstrate a critically important contribution of apoE to CAA pathogenesis.

\section{Materials and Methods}

Animals and tissue preparation. The production, genotyping, and background strain (B6/SJL) of APPsw (Tg2576) and APPsw, Apoe-/- mice ages 12-18 months used in this study have been described previously (Hsiao et al., 1996; Holtzman et al., 2000a). APPsw mice overexpress human $\mathrm{APP}_{695}$ with the familial Swedish $\mathrm{AD}$ mutations at positions 670 / 671 under control of the prion promoter and were a generous gift from Dr. K. Ashe (University of Minnesota, Minneapolis, MN). The production, genotyping, and background strains of PDAPP and PDAPP, Apoe-/- mice ages 15-24 months used in this study have been described previously (Games et al., 1995; Bales et al., 1997; Holtzman et al., 1999). PDAPP mice overexpress human $\mathrm{APP}_{751}$ with the familial AD mutation at position $717\left(\mathrm{APP}^{\mathrm{V} 717 \mathrm{~F}}\right)$ under control of the neuronal-specific platelet-derived growth factor promoter. Animals were anesthetized with pentobarbital (150 mg/kg, i.p.) and perfused transcardially with $0.1 \mathrm{M}$ PBS containing heparin $(3 \mathrm{U} / \mathrm{ml}), \mathrm{pH}$ 7.4. One hemibrain was immersion-fixed in PBS containing 4\% paraformaldehyde overnight at $4^{\circ} \mathrm{C}$. After fixation, the brain was cryoprotected in PBS containing 30\% sucrose at $4^{\circ} \mathrm{C}$. All experimental protocols were approved by the animal studies committee at Washington University.

Histological analysis. Coronal sections $(50 \mu \mathrm{m})$ were cut on a freezingsliding microtome and mounted on Superfrost Plus slides (Fisher Scientific, Houston, TX) and permeabilized with PBS containing $0.25 \%$ Triton X-100 (PBS-X) for 30 min at room temperature (RT). Every sixth section from the genu of the corpus callosum to the caudal end of the hippocampus (20-25 sections per animal) was examined. To assess for evidence of previous microhemorrhage, the Prussian Blue stain was performed as described (Gomori, 1936; Winkler et al., 2001). The Prussian Blue reagent stains microglia that have engulfed ferric iron-containing hemosiderin from red blood cells, indicating a previous hemorrhage. Briefly, sections were washed twice quickly in deionized water and incubated in $2 \% \mathrm{HCl}$ containing $2 \%$ potassium ferrocyanide for $20 \mathrm{~min}$. Slides were rinsed three times in PBS, coverslipped with 70\% glycerol, and examined with a $10 \times$ objective for blue puncta. Microhemorrhage was defined as having at least two blue puncta surrounding a cerebral vessel. To confirm that microhemorrhage was associated with CAA (as shown in Fig. 1), the sections were costained with thioflavine-S as described previously (Bales et al., 1997). Prussian blue stain was always imaged first because of extremely rapid dissolution of the blue precipitate after UV excitation required for thioflavine-S imaging. For triple-label immunohistochemistry, sections were blocked with $2 \%$ dry milk-PBS-X for $1 \mathrm{hr}$ at RT. Sections were then incubated with rabbit anti-mouse apoE sera (generous gift from Dr. R. Pitas, Gladstone Institute, University of California San Francisco) at 1:500 dilution in $1 \%$ dry milk-PBS-X overnight at $4^{\circ} \mathrm{C}$. Sections were washed three times with PBS-X and incubated with goat anti-rabbit conjugated with Alexa-568 (Molecular Probes, Eugene, OR) in $1 \%$ milk-PBS for $1 \mathrm{hr}$ at RT. Sections were washed three times with PBS-X and then incubated with a monoclonal antibody, m3D6 (Johnson-Wood et al., 1997) directed against the A $\beta$ peptide (amino acid residues 1-5) conjugated with Alexa-488 in 1\% dry milk-PBS. Sections were washed three times in PBS-X and then stained for fibrillar amyloid with the Congo red derivative X-34 dye (generous gift from Dr. W. Klunk, University of Pittsburgh, Pittsburgh, PA). This dye has the advantage of narrow emission spectra compared with thioflavine-S, which has fluorescent emission well into the 488 range (Styren et al., 2000). Fluorescein-conjugated monoclonal antibody against smooth muscle actin (Accurate Chemical, Westbury, NY) was used with Alexa 488 tyra- mide signal amplification using anti-fluorescein-peroxidase (Molecular Probes) and imaged on a Zeiss LSM 510 META laser scanning confocal microscope (Carl Zeiss, Jena, Germany).

Quantitation of CAA and $A \beta$ load. The percentage of cross-sectional area covered by CAA vessels (percentage CAA load) as defined by thioflavine-S-positive vessels was quantified using unbiased stereological principles. CAA load was determined in the cortex and overlying leptomeningeal vessels immediately dorsal to the hippocampus in three sections, each separated by $300 \mu \mathrm{m}$. StereoInvestigator image analysis software (MicroBrightField, Williston, VT) was used to quantify percentage CAA load using the Cavalieri point counting method (Cavalieri, 1966). Percentage $A \beta$ load in hippocampus was quantified using stereological techniques as described previously (DeMattos et al., 2002).

Isolation of cerebral vessels and parenchymal tissue. The isolation of cerebral vessels for biochemical analysis was performed essentially as described (Zlokovic et al., 1993) with minor modifications. Briefly, animals were anesthetized and perfused transcardially with $0.1 \mathrm{M}$ PBS with heparin $(3 \mathrm{U} / \mathrm{ml})$. The brain was removed gently and placed in ice-cold vessel buffer consisting of HBSS (Invitrogen, Carlsbad, CA) containing $15 \mathrm{~mm}$ HEPES, $1 \mathrm{~mm}$ pyruvate, $25 \mathrm{~mm}$ glucose, $25 \mathrm{~mm} \mathrm{NaHCO}, 0.1 \%$ $\mathrm{BSA}$, and $1 \%$ dextran $(\sim 64,000 \mathrm{~mol}$ weight $)$. After the cerebellum was removed, the brain was homogenized in a loose-fitting glass Dounce homogenizer in fivefold excess of vessel buffer. An equal volume of $26 \%$ dextran was added for a final concentration of $13.5 \%$, and the tissue was immediately centrifuged at $6200 \times g$ in a Beckman SW40 Ti ultracentrifuge swinging bucket rotor for $30 \mathrm{~min}$ at $4^{\circ} \mathrm{C}$. Using this protocol, the vessels form a pellet, whereas the parenchymal "vessel-free" material forms a solid, compact disc at the top of the solution with little protein in the clear interface between the vessel pellet and the parenchymal disc. This parenchymal material was gently aspirated with a transfer pipette, collected in a conical tube with $50 \mathrm{ml}$ of ice-cold PBS, and centrifuged at $2000 \times g$ to pellet the material. The parenchymal pellet was washed once with vessel buffer (minus dextran and BSA). The vessel pellet was resuspended in $10 \mathrm{ml}$ of vessel buffer (minus dextran) and passed over a $40 \mu \mathrm{m}$ nylon mesh (Fisher Scientific) to capture vessels. Vessels were washed extensively with vessel buffer (minus dextran) and were recovered by inverting the mesh and collecting into a $50 \mathrm{ml}$ conical tube with a stream of vessel buffer (minus dextran). Vessels were spun in a tabletop centrifuge at $2000 \times g$ and washed once with $30 \mathrm{ml}$ of vessel buffer (minus dextran). Purity of similarly prepared samples was verified by light microscopy. Vessel and parenchymal material were lysed in $5 \mathrm{~m}$ guanidine, $50 \mathrm{~mm}$ Tris, $\mathrm{pH} 8$, with protease inhibitor mixture (Roche, Indianapolis, IN) and $1 \mathrm{~mm}$ PMSF (Sigma, St. Louis, MO) rotating for $3 \mathrm{hr}$ at RT.

Acid-urea gel and ELISA. Denaturing acid-urea PAGE followed by immunoblotting was used to identify forms of $A \beta$ in tissue lysates as described previously (DeMattos et al., 2002). $\mathrm{A} \beta_{40}$ and $\mathrm{A} \beta_{42}$ were quantified by ELISA as described previously (DeMattos et al., 2001).

Statistical analysis. Because CAA load and microhemorrhage data were not distributed normally, Mann-Whitney two-tailed $t$ test was used to compare APPsw, Apoe ${ }^{+/+}$with APPsw, Apoe - /- mice or PDAPP, Apoe ${ }^{+/+}$with PDAPP, Apoe $-/-$mice at the same age in regard to percentage CAA load or microhemorrhage. To compare $A \beta$ levels by ELISA and $A \beta$ deposition between PDAPP and APPsw mice of the same age, a two-tailed $t$ test was used. For statistical analyses, Prism version 3.00 software was used (GraphPad, San Diego, CA).

\section{Results}

Age-dependent CAA and associated microhemorrhage occur in APPsw and PDAPP mice

Of the numerous APP transgenic mice that have been described that develop $\mathrm{A} \beta$ deposits in the brain, spontaneous intracerebral microhemorrhage in association with CAA has been reported previously in only one type of these APP transgenic models (Winkler et al., 2001, 2002; Pfeifer et al., 2002). We first set out to determine whether other mouse models with $\mathrm{A} \beta$ deposition also have evidence of CAA and spontaneous microhemorrhage in association with CAA. The APPsw model shows a more severe CAA phenotype than does the PDAPP model at equivalent ages, despite 
Table 1. Comparison of $A \beta$ levels and parenchymal plaque load between APPsw and PDAPP models

\begin{tabular}{|c|c|c|c|c|c|}
\hline & $\mathrm{A} \beta 40 \mathrm{pg} / \mu \mathrm{g}$ & $\mathrm{A} \beta 42 \mathrm{pg} / \mu \mathrm{g}$ & $A \beta 40+42 \mathrm{pg} / \mu \mathrm{g}$ & $A \beta 40: 42$ ratio & $\%$ Non-CAA A $\beta$ load \\
\hline \multicolumn{6}{|l|}{ APPsw } \\
\hline 3 months & $5.8^{*}$ & 5.3 & 11.1 & $1.30^{*}$ & 0 \\
\hline $11-12$ months & $115.3^{*}$ & 46.8 & 162.1 & $2.34^{*}$ & $2.56^{*}$ \\
\hline $15-16$ months & $267.1^{*}$ & $118.7^{*}$ & $385.9^{*}$ & $2.22^{*}$ & 19.37 \\
\hline \multicolumn{6}{|l|}{ PDAPP } \\
\hline 3 months & 1.8 & 3.72 & 5.47 & 0.46 & 0 \\
\hline $11-12$ months & 27.4 & 449.9 & 477.3 & 0.08 & 19.67 \\
\hline $15-16$ months & 84.7 & 920.2 & 1004.9 & 0.10 & 28.88 \\
\hline
\end{tabular}

A $\beta$ ELISA analysis $(\mathrm{pg} / \mu \mathrm{g})$ of hippocampal lysates from both APPsw and PDAPP mice reveals an elevated ratio of A $\beta$ 40:42 in APPsw mice at all ages examined. PDAPP mice have a higher parenchymal (non-CAA) plaque load than APPsw mice. ${ }^{*} p<0.05$ comparing APPsw with PDAPP mice at the same age ( $n \geq 4$ per group).
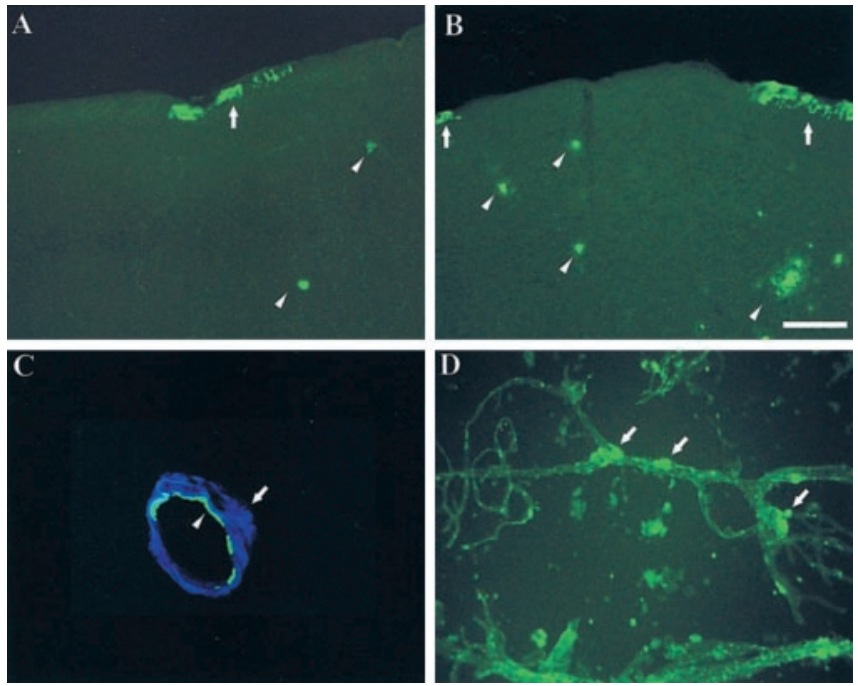

Figure 1. CAA is present in both the APPsw and PDAPP mouse models of AD. Thioflavine-S staining of sections from a 12-month-old APPsw mouse $(A)$ and a 24-month-old PDAPP mouse (B) demonstrating amyloid in cerebral vessels (arrows). Although the PDAPP model does develop CAA, the pathology is less extensive at equivalent ages when compared with the APPsw model. Also shown are parenchymal plaques (arrowheads). C, Two-photon image of CAA vessel from an 18-month-old APPsw mouse immunostained for smooth muscle actin (green, arrowhead) surrounded by amyloid (blue, arrow). D, Isolated cerebral vessels from a 27 -month-old PDAPP mouse stained with thioflavine-S demonstrating presence of amyloid (arrows) in vessels. Scale bar: $A, B, 100 \mu \mathrm{m}$.

higher $\mathrm{A} \beta$ parenchymal plaque load and total $\mathrm{A} \beta$ levels in PDAPP mice at 12 and 15 months of age (Table 1 ). $A \beta$ deposition in the form of both diffuse and fibrillar parenchymal plaques begins at 7-10 months of age in both PDAPP and APPsw mice. CAA occurs concurrently in APPsw mice. By 12 months of age, CAA is more prominent in APPsw mice with comparable levels not seen in PDAPP mice until 24 months of age (Fig. $1 A, B$ ). The difference in CAA severity between the two animal models may be attributable to the fact that at both young and older ages, APPsw mice have higher brain tissue levels of $\mathrm{A} \beta_{40}$ and an increased ratio of A $\beta$ 40:42 (Table 1). CAA from both models is typical of that seen in other mouse models and in human CAA cases, with a ring of amyloid surrounding the vessel wall (Fig. 1C). The presence of CAA can also be seen in isolated cerebral vessels from APP transgenic mice (Fig. 1D). We found that once CAA was demonstrable, microhemorrhages occurred in association with CAA in both APPsw and PDAPP mice (Fig. 2). Microhemorrhages were associated almost exclusively with amyloid-containing vessels (identified as thioflavine-S positive). Although more rare, occasional macrohemorrhages associated with CAA were also seen in APPsw mice 15 months of age and older.

\section{APPsw 18 month}
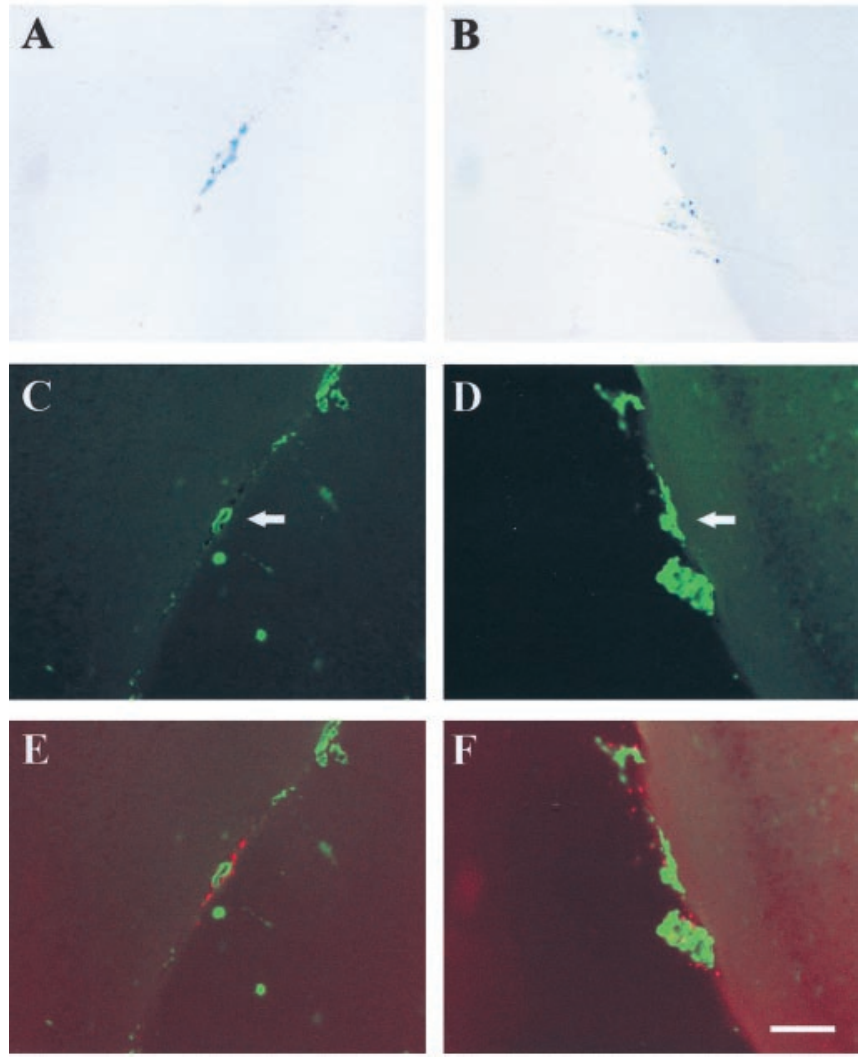

Figure 2. CAA and associated microhemorrhage occur in both the aged APPsw and PDAPP mice. $A, B$, Prussian Blue staining indicates microhemorrhage in an 18-month-old APPsw mouse and 24-month-old PDAPP mouse, respectively. C, D, Thioflavine-S-positive vessels (arrows) in an 18-month-old APPsw mouse and 24-month-old PDAPP mouse, respectively. $E, F$, Merged images of $A$ and $C$ and $B$ and $D$ showing colocalization of microhemorrhage (red) with CAA (green). Prussian Blue images were digitally converted to red using Adobe Photoshop. Scale bar, $100 \mu \mathrm{m}$.

CAA load increased with age in both the APPsw and PDAPP models (Fig. $3 A, C$ ); however, the absolute amount of CAA in the APPsw model is far greater than in the PDAPP model at the same age. In 15-month-old mice, the percentage cortical CAA load (percentage area of the cortex and overlying leptomeninges covered by CAA) in APPsw mice is 1.46 versus $0.38 \%$ in PDAPP mice (Fig. $3 A, C$ ). Cerebral microhemorrhage also increased with age in the APPsw and PDAPP models (Fig. $3 B, D$ ). Although there was a substantial increase in microhemorrhages between 12 and 

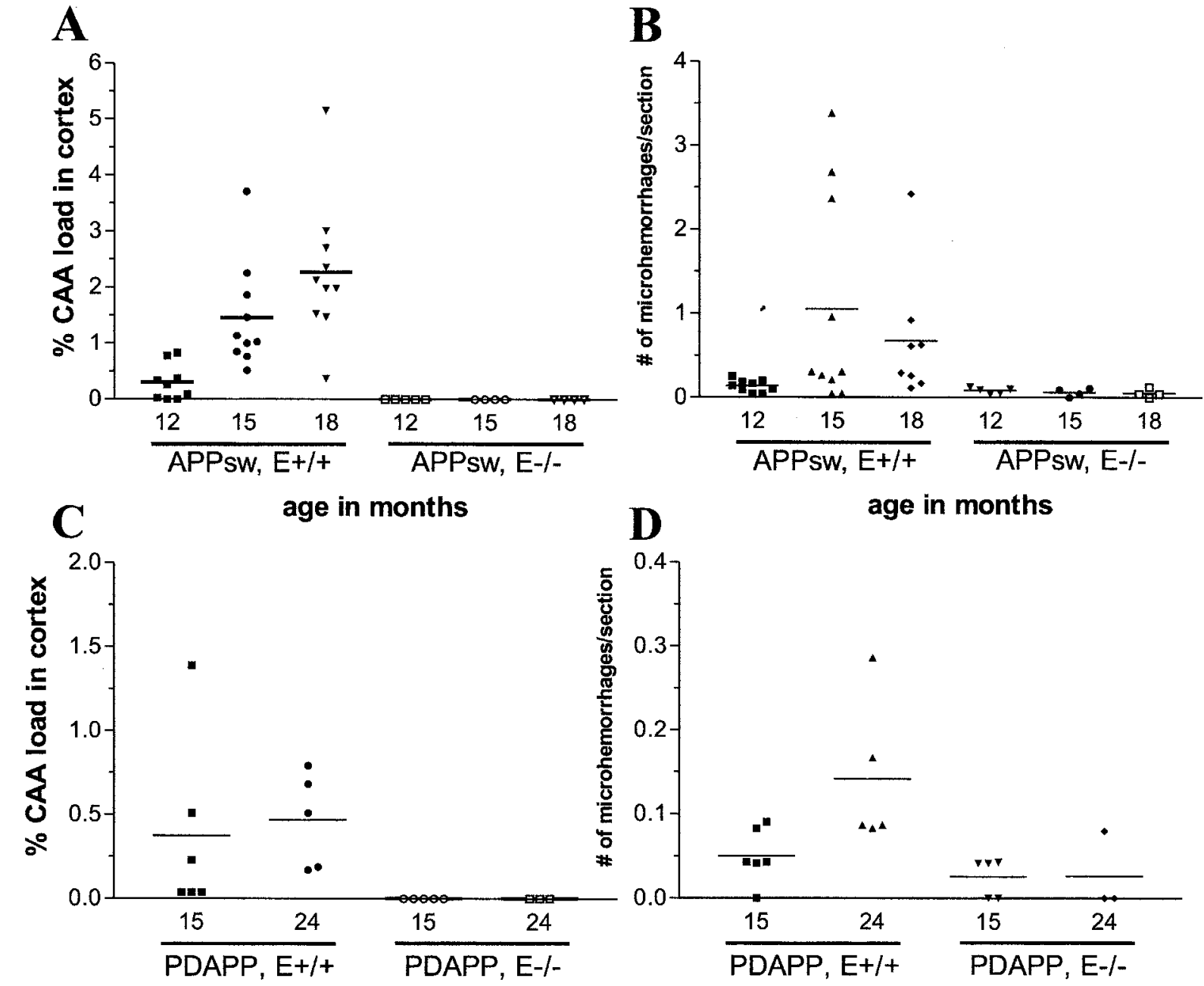

age in months

D

age in months

Figure 3. Age-dependent CAA and microhemorrhage in APP transgenic mice is prevented in the absence of apoE. A, CAA load increases with age in the cortex of 12-, 15-, and 18-month-old APPsw, Apoe ${ }^{+1+}$ mice. APPsw, Apoe- $1-$ mice have a significant reduction $(p<0.05)$ in CAA at 15 and 18 months. $B$, The frequency of microhemorrhage also increases in $12-, 15-$, and 18-month-old APPsw, Apoe $+/+$ mice. APPsw, Apoe- - - mice have a significant reduction $(p<0.05)$ in microhemorrhage at 15 and 18 months. $C$, CAA load increases in the cortex between 15 and 24 months of age in PDAPP, Apoe ${ }^{+/+}$mice. PDAPP, Apoe - / - mice have a significant reduction $(p<0.05)$ in CAA at 15 and 24 months of age as compared with PDAPP, Apoe $+/+$ mice. $D$, The frequency of microhemorrhage increases in 15 - and 24-month-old mice. PDAPP, Apoe - / - mice have a significant reduction ( $p<0.05)$ in microhemorrhage at 15 and 18 months as compared with PDAPP, Apoe $+1+$ mice.

15 months of age in APPsw mice, the number of hemorrhages at 15 and 18 months was not statistically different.

\section{ApoE promotes CAA and associated microhemorrhage in APPsw and PDAPP mice}

We sought to determine whether apoE, forms of which are associated with altered risk of CAA and hemorrhage, is directly involved in the pathogenesis of CAA. Previous results have shown that murine apoE promotes parenchymal amyloid deposition as well as CAA up to 12 months of age in the APPsw model (Holtzman et al., 2000a). The effect of apoE on CAA at older ages and whether it influences CAA-associated hemorrhage is unknown. We first asked whether apoE directly associates with CAA in APPsw mice. ApoE immunoreactivity colocalized to many parenchymal and cerebrovascular deposits of $\mathrm{A} \beta$ in the form of amyloid in APPsw mice (Fig. 4). Similar results were obtained in PDAPP mice (data not shown). We next examined the development of CAA in APPsw and PDAPP mice lacking apoE between 12 and 24 months of age. Strikingly, even up to 18 months of age, a time when there is otherwise substantial CAA in APPsw mice, none of the APPsw, Apoe-/- mice $(n=13)$ developed any detectable CAA (Fig. $3 A$ ). The absence of CAA was also associated with a dramatically reduced number of microhemorrhages up to 18 months of age in APPsw, Apoe-/- mice (Fig. 3B). Similar effects of apoE were also seen in the PDAPP model. None of the PDAPP, Apoe- $/-$ mice studied $(n=8)$ had evidence of CAA in any brain region up to 24 months of age (minimum of 20 sections sampled per brain) (Fig. 3C). There was also a decrease in the number of microhemorrhages in PDAPP, Apoe- $/-$ mice up to 24 months of age (Fig. 3D). This dramatic effect of apoE on CAA is remarkable given that although there is a delay in thioflavine$\mathrm{S}$-positive amyloid deposition in the absence of apoE, $\mathrm{A} \beta$ still deposits as amyloid in the parenchyma of aged APPsw, Apoe-/mice (Fig. 4) as has been reported previously in very old (18-24 months) PDAPP mice (Fagan et al., 2002). PDAPP, Apoe-/mice, up to 24 months of age, had no CAA despite the presence of thioflavine-S-positive amyloid in the brain parenchyma of most of these animals at old ages (Fagan et al., 2002). 


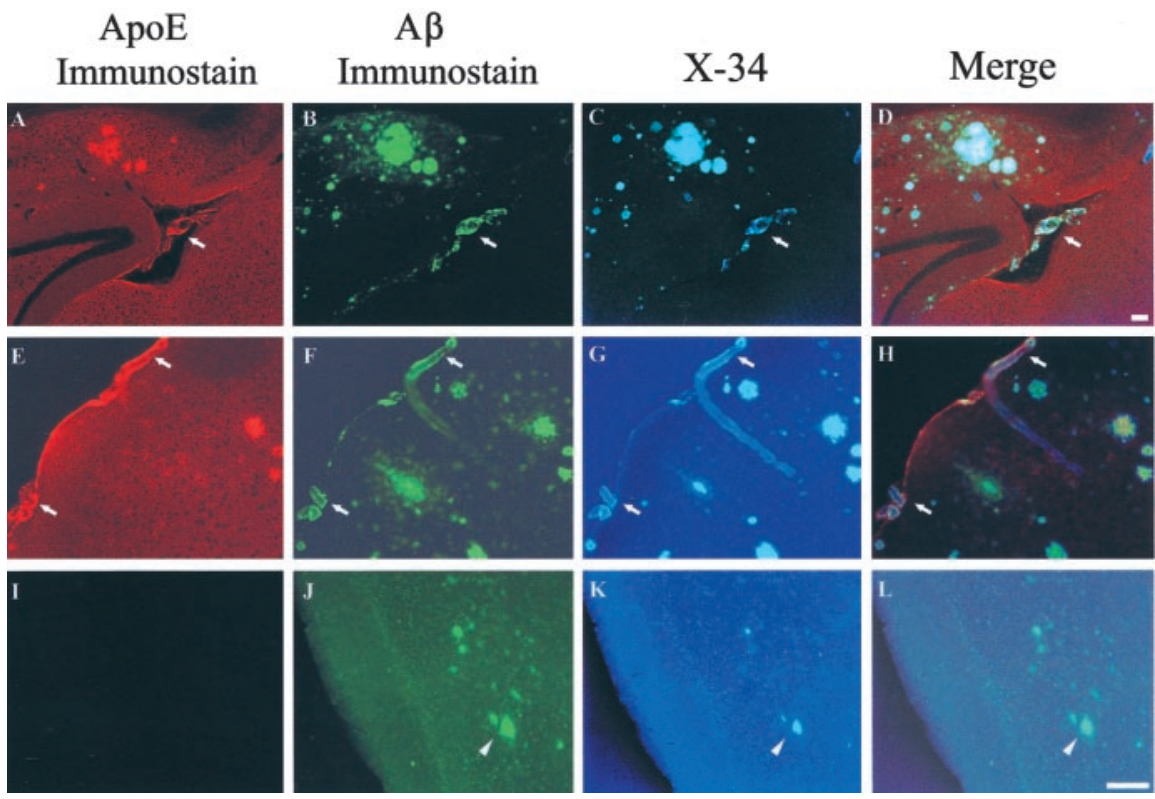

Figure 4. Triple-labeling demonstrates apoE colocalization to CAA in vessels (arrows) in APPsw mice. Eighteen-month-old APPsw mice $(A-H)$ and 18-month-old APPsw, Apoe- I- mice $(I-L)$ were immunostained for apoE $(A, E, I)$ and $A \beta(B, F, J)$ and with the Congo red derivative $X$-34 as a marker of fibrillar amyloid $(C, G, K)$. Although fibrillar $A \beta$ (arrowheads) begins to deposit in the parenchyma of old APPsw, Apoe - / - mice at later ages, no evidence for CAA was found in these same mice. Scale bars: (shown in $D$ for $A-D$; shown in $L$ for $E-L$ ), $100 \mu \mathrm{m}$.

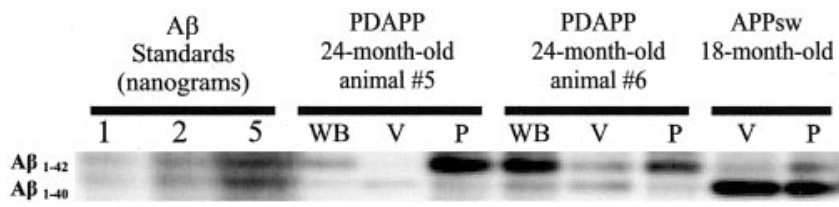

Figure 5. Ratio of $A \beta 40: 42$ is increased in cerebral blood vessels of APPsw and PDAPP mice shown in Table 2. Shown is immunoblot of cerebral vessels and parenchymal brain tissue lysates run on acid-urea polyacrylamide gels to differentiate $A \beta 1-40$ and 1-42. Both the 18-monthold APPsw and 24-month-old PDAPP mice tested revealed an elevated ratio of A $\beta$ 40:42 in cerebral vessel lysates as compared with brain parenchyma. Immunoblots were probed with an anti-A $\beta$ antibody mixture of 3D6 (N-terminal specific), $21 \mathrm{~F} 12$ (42 specific), and 266 (central domain specific). WB, Whole brain; $V$, vessels; $P$, parenchyma.

\section{Ratio of $A \beta 40$ to $A \beta 42$ is markedly increased in cerebral} vessels of aged APPsw and PDAPP mice: dependence on apoE Previous biochemical experiments from human brain as well as immunohistochemical staining in APP transgenic mouse brain suggest that, in contrast to parenchymal plaques in which there is an enrichment of $\mathrm{A} \beta_{42}$, there is a relative increase in $\mathrm{A} \beta_{40}$ associated with CAA (Joachim et al., 1988; Prelli et al., 1988; Suzuki et al., 1994; Alonzo et al., 1998; McCarron et al., 2000). Because apoE dramatically influenced both the deposition of amyloid in cerebral vessels as well as one of its consequences (i.e., microhemorrhage), we sought to determine whether the ratio of $\mathrm{A} \beta_{40}$ to $A \beta_{42}(40: 42)$ was altered in the cerebral blood vessels of aged PDAPP and APPsw mice in the presence and absence of apoE. Biochemical assessment of cerebral vessels isolated from 24month-old PDAPP mice by acid-urea gel electrophoresis followed by Western blotting showed a marked increase in the ratio of A $\beta$ 40:42 compared with whole brain or parenchymal lysate (Fig. 5, Table 2). $\mathrm{A} \beta_{40^{-}}$and $\mathrm{A} \beta_{42}$-specific ELISA analysis confirmed this elevated ratio in vessel preparations (Table 2). Of the two aged 24-month-old PDAPP mice examined, PDAPP animal 5 showed a 20-fold increase in the ratio of $A \beta$ 40:42 in cerebral vessels $(40: 42$ ratio $=6.1)$ compared with whole brain lysate
$(40: 42$ ratio $=0.3)$, whereas animal 6 showed a more modest threefold increase (ratio of $\mathrm{A} \beta$ 40:42 of 1.1 for vessel vs 0.4 for whole brain) (Table 2). Of the two aged PDAPP, Apoe-/- mice examined, both animals had a very low ratio of $A \beta$ 40:42 in cerebral vessels as well as in whole-brain lysate. Animal 7 had a ratio of $A \beta$ 40:42 in cerebral vessels of 0.08 , and animal 8 had a ratio of $A \beta 40: 42$ of 0.16 (Table 2). In the one 18-month-old APPsw mouse examined biochemically, the vessels and brain parenchyma both had a high ratio of $\mathrm{A} \beta$ $40: 42$, although this ratio was much higher in vessels (19.4) versus brain parenchymal material (5.7). We also examined the ratio of $A \beta 40: 42$ in young PDAPP mice in the presence and absence of apoE. The ratio of A $\beta$ 40:42 was similar in both groups ( $\mathrm{Ta}$ ble 2 ). This suggests that the combination of apoE together with the levels of $\mathrm{A} \beta_{40}$ or ratio of $\mathrm{A} \beta$ 40:42 predispose to CAA.

\section{Discussion}

Although there is considerable data on factors that facilitate parenchymal A $\beta$ deposition, less is known about mechanisms leading to CAA. We used two different mouse models with $\mathrm{A} \beta$ deposition, PDAPP and APPsw transgenic mice, to investigate the effects of apoE expression on CAA and associated microhemorrhage. We demonstrate that both of these models develop an age-dependent deposition of $A \beta$ in the form of amyloid in cerebral vessels, with the APPsw model developing more severe pathology. We also show that a major consequence of CAA (i.e., hemorrhage) also occurs in an agedependent manner in these models. Although the effect of apoE on parenchymal amyloid deposition has been well studied, much less is known about its role in CAA. We show here, in both the PDAPP and APPsw mice, that the age-dependent development of CAA is prevented completely in the absence of apoE in animals examined up to 24 months of age. The latter occurs despite deposition of $A \beta$ in the parenchyma in all of these animals, some of which is fibrillar (thioflavine-S positive) at older ages. Of note, $\mathrm{A} \beta$ deposition in blood vessels of PDAPP and APPsw mice is all fibrillar, and there does not appear to be diffuse $\mathrm{A} \beta$ deposits in vessels. Thus, the effect of removing apoE is not to delay conversion of diffuse deposits to fibrillar deposits; it prevents the conversion directly from soluble to fibrillar $\mathrm{A} \beta$. Importantly, and concomitant with the prevention of CAA, there is an almost complete absence of microhemorrhages in the Apoe-/- mice. Additionally, as is the case in human patients with CAA, cerebral vessels isolated from aged PDAPP and APPsw mice with CAA have an elevated amount of $\mathrm{A} \beta_{40}$ relative to $\mathrm{A} \beta_{42}$; however, cerebral vessels isolated from aged PDAPP, Apoe-/- mice have a dramatically reduced ratio of A $\beta$ 40:42. Taken together, our results demonstrate that in addition to the levels of $\mathrm{A} \beta_{40}$ and the ratio of $\mathrm{A} \beta 40: 42$, apoE plays a critical role in CAA formation and its consequences.

CAA is a major cause of often fatal lobar cerebral hemorrhage (Vinters, 1987). Although mutations in APP outside of the A $\beta$ coding region result in rare forms of familial AD (Goate et al., 1991; Tanzi and Bertram, 2001), it has also been found that familial mutations within the $\mathrm{A} \beta$ coding region itself give rise to 
Table 2. Ratio of $A \beta 40: 42$ is increased in vessels from aged mice with CAA and is dependent on apoE

\begin{tabular}{|c|c|c|c|}
\hline & Ratio of $A \beta 4$ & & \\
\hline & Whole brain & Parenchyma & Vessel \\
\hline 3 month APPsw & ND & 2.65 & 1.48 \\
\hline 18 month APPsw & ND & 5.7 & 19.4 \\
\hline 4 month PDAPP \#1 & 0.27 & 0.28 & 0.19 \\
\hline 4 month PDAPP \#2 & 0.29 & 0.32 & 0.2 \\
\hline 4 month PDAPP, E-/-\#3 & 0.24 & 0.33 & 0.18 \\
\hline 4 month PDAPP, E-/- \#4 & 0.32 & 0.34 & 0.07 \\
\hline 24 month PDAPP \#5 & 0.3 & 0.3 & 6.1 \\
\hline 24 month PDAPP \#6 & 0.4 & 0.5 & 1.1 \\
\hline 22 month PDAPP, E-I- \#7 & 0.05 & 0.01 & 0.08 \\
\hline 21 month PDAPP, E-/-\#8 & 0.07 & 0.05 & 0.16 \\
\hline
\end{tabular}

$A \beta$ ELISA analysis of brain and vessel lysates confirms an elevated ratio of $A \beta 40: 42$ in cerebral vessels of aged APPsw and PDAPP mice. Cerebral vessel lysates from aged PDAPP, Apoe - / - mice have an extremely low ratio of $A \beta 40: 42$. The $A \beta 40: 42$ ratio in young PDAPP, Apoe $-/-$ mice is similar to that in young PDAPP mice. The levels of $A \beta_{40}$ and $A \beta_{42}$ in blood vessels could not be normalized to vessel protein because of the small amount of vessel tissue. In these young PDAPP and APPsw mice, $\sim 0.5-1 \%$ of brain $A \beta$ is associated with vessels. In old mice, $\sim 1-5 \%$ of brain $A \beta$ is associated with vessels in PDAPP mice and $\sim 10-30 \%$ in APPsw mice. ND, Not determined.

severe forms of CAA, including hereditary cerebral hemorrhage with amyloidosis Dutch-type (Levy et al., 1990; Revesz et al., 2002) and Italian-type (Tagliavini et al., 1999). Other clinically relevant effects of CAA, such as ischemia, are just now beginning to be investigated (Greenberg, 2002). A recently described mutation within the $\mathrm{A} \beta$ region in an Iowa family is associated with dementia and severe CAA but not cerebral hemorrhage (Grabowski et al., 2001). Interestingly, many of the mutations that result in familial AD appear to result from an increase in production of $\mathrm{A} \beta_{42}$, a particularly amyloidogenic form of $\mathrm{A} \beta$ (Citron et al., 1992, 1997; Cai et al., 1993; Haass et al., 1994; Borchelt et al., 1996, 1997; Eckman et al., 1997). Mutations in APP that lead to CAA do not appear to increase $A \beta$ production, but in some way alter its fibrillogenic properties, toxicity, and clearance (Levy et al., 1990; Davis and Van Nostrand, 1996; Miravalle et al., 2000; Grabowski et al., 2001; Nilsberth et al., 2001; Van Nostrand et al., 2001; Monro et al., 2002).

Characterization of suitable animal models is necessary to study the pathogenesis of and potential treatment strategies for CAA as well as AD. Recently, Jucker and colleagues (Winkler et al., 2001) demonstrated that the APP23 mouse model of AD, in which the neuron-specific thy-1 promoter is used to drive expression of APPsw, also develops extensive CAA and has an agedependent increase in microhemorrhages. Our data show that hemorrhage associated with CAA occurs in two other commonly used APP transgenic mice and that the APPsw mutation favors the formation of CAA and hemorrhage as compared with the $\mathrm{APP}^{\mathrm{V717F}}$ mutation. Recently, Jucker and colleagues (Pfeifer et al., 2002) showed that a passively administered $\mathrm{N}$-terminal A $\beta$ antibody resulted in an increase in CAA-associated hemorrhage. The exact cause of this effect has yet to be delineated, although it may have been caused by the antibody recognizing $A \beta$ in an amyloid conformation in the vessel wall. Our results presented here indicate that the PDAPP and APPsw models also display this hemorrhage phenotype and may be useful in examining and defining future immunization strategies.

In 1993 the $\epsilon 4$ allele of $A P O E$ was shown to be a genetic risk factor for developing AD (Corder et al., 1993; Rebeck et al., 1993; Strittmatter et al., 1993) and subsequently also found to be a risk factor for CAA (Schmechel et al., 1993; Greenberg et al., 1995; Nicoll et al., 1997). Additionally, in patients who have sustained brain hemorrhage attributable to CAA, there is an overrepresentation of $\epsilon 2$ allele of APOE (Greenberg et al., 1996, 1998; Nicoll et al., 1996). Several lines of evidence demonstrate that apoE interacts with $\mathrm{A} \beta$ both in vitro (Strittmatter et al., 1993; Wisniewski et al., 1993; LaDu et al., 1994; Munson et al., 2000) and in vivo (Naslund et al., 1995; Wisniewski et al., 1995; Permanne et al., 1997; Russo et al., 1998). Previously it has been shown that murine apoE markedly facilitates the fibrillogenesis of $\mathrm{A} \beta$ in brain parenchyma in vivo in the PDAPP model (Bales et al., 1997, 1999; Holtzman et al., 1999, 2000b) as well as parenchymal and cerebrovascular amyloid in the APPsw model up to 12 months of age (Holtzman et al., 2000a).

Murine apoE has a profound effect on the development of $\mathrm{CAA}$ and its consequences. Furthermore, the effect of apoE is even more profound on the deposition of $A \beta$ in cerebral vessels than it is on deposition of $A \beta$ in brain parenchyma. The reason for this difference is unknown. Clearance of $A \beta_{40}$ from the brain has been suggested to occur via active transport across the bloodbrain barrier (Ghersi-Egea et al., 1996; Shibata et al., 2000; Ji et al., 2001) as well as along peri-arterial interstitial fluid drainage pathways into cervical lymph nodes and then into peripheral circulation (Weller et al., 1998). The basement membrane along periarterial drainage pathways contains an abundance of molecules known to bind apoE, such as heparin sulfate proteoglycans (Strittmatter and Bova Hill, 2002). In addition, endothelial cells that make up the blood-brain barrier express apoE receptors such as low-density lipoprotein receptor family members (Zlokovic et al., 1996; Shibata et al., 2000). If apoE-A $\beta$ complexes remain bound to these molecules, it could provide a different environment attributable to factors such as charge and surface structure that facilitates $\mathrm{A} \beta$ fibrillogenesis. Whether apoE derived from different species (i.e., rodent versus human) and different human apoE isoforms will have similar effects on $\mathrm{A} \beta$ accumulation in the form of CAA is not known. Previous studies suggest that human apoE, in addition to playing a role in $\mathrm{A} \beta$ fibrillogenesis, may also play an important role in $\mathrm{A} \beta$ clearance from brain parenchyma (Holtzman et al., 1999; Fagan et al., 2002). Whether it also plays a role in influencing $A \beta$ clearance in relation to CAA remains to be defined.

Our findings also support the hypothesis that alterations in $\mathrm{A} \beta$ metabolism, such as the ratio of $\mathrm{A} \beta$ 40:42, may be a key pathologic event in the development of CAA. The increase in ratio of $A \beta$ 40:42 in cerebral vessels with CAA is in close agreement with previous observations in humans with CAA (Joachim et al., 1988; Prelli et al., 1988; Suzuki et al., 1994; Alonzo et al., 1998; McCarron et al., 2000). A biochemical analysis of one mouse model of $\mathrm{AD}$ with a significant $\mathrm{CAA}$ component, the APP/Ld model, found that the vessels isolated from these aged mice had an eightfold increase in the ratio of $\mathrm{A} \beta$ 40:42 as compared with brain parenchyma (Van Dorpe et al., 2000). The $\mathrm{APP}^{\mathrm{V717F}}$ mutation results in a low ratio of $\mathrm{A} \beta$ 40:42 compared with the $\mathrm{APP}^{670 / 671}$ Swedish mutation (Hsiao et al., 1996; Johnson-Wood et al., 1997). Humans and mice with the $\mathrm{APP}^{\mathrm{V} 717 \mathrm{~F}}$ mutation have little CAA (Murrell et al., 1991), whereas humans and mice with the APP ${ }^{670 / 671}$ Swedish mutation have substantial CAA (Lannfelt et al., 1994). Despite developing greater overall levels of parenchymal A $\beta$ load, PDAPP mice have less CAA than APPsw mice. This may be attributable to the fact that APPsw mice have higher levels of $\mathrm{A} \beta_{40}$ and an increase in the ratio of $A \beta$ 40:42 compared with PDAPP mice at young and older ages. Although the ratio of $\mathrm{A} \beta$ 40:42 does not appear to be altered by apoE at young ages, there is a further reduction in this ratio in older PDAPP mice lacking apoE. Taken together, this suggests that levels of $\mathrm{A} \beta_{40}$ and the ratio of $\mathrm{A} \beta 40: 42$ combined with apoE influence the probability of CAA formation. Determining how 
apoE influences the development of CAA and its consequences such as cerebral hemorrhage may lead to new insights into the pathogenesis and treatment of CAA.

\section{References}

Alonzo NC, Hyman BT, Rebeck GW, Greenberg SM (1998) Progression of cerebral amyloid angiopathy: accumulation of amyloid-beta40 in affected vessels. J Neuropathol Exp Neurol 57:353-359.

Bales KR, Verina T, Dodel RC, Du Y, Altstiel L, Bender M, Hyslop P, Johnstone EM, Little SP, Cummins DJ, Piccardo P, Ghetti B, Paul SM (1997) Lack of apolipoprotein $\mathrm{E}$ dramatically reduces amyloid beta-peptide deposition. Nat Genet 17:263-264.

Bales KR, Verina T, Cummins DJ, Du Y, Dodel RC, Saura J, Fishman CE, DeLong CA, Piccardo P, Petegnief V, Ghetti B, Paul SM (1999) Apolipoprotein $\mathrm{E}$ is essential for amyloid deposition in the APP(V717F) transgenic mouse model of Alzheimer's disease. Proc Natl Acad Sci USA 96:15233-15238.

Borchelt DR, Thinakaran G, Eckman CB, Lee MK, Davenport F, Ratovitsky T, Prada CM, Kim G, Seekins S, Yager D, Slunt HH, Wang R, Seeger M, Levey AI, Gandy SE, Copeland NG, Jenkins NA, Price DL, Younkin SG, Sisodia SS (1996) Familial Alzheimer's disease-linked presenilin 1 variants elevate Abeta1-42/1-40 ratio in vitro and in vivo. Neuron 17:1005-1013.

Borchelt DR, Ratovitski T, van Lare J, Lee MK, Gonzales V, Jenkins NA, Copeland NG, Price DL, Sisodia SS (1997) Accelerated amyloid deposition in the brains of transgenic mice coexpressing mutant presenilin 1 and amyloid precursor proteins. Neuron 19:939-945.

Cai XD, Golde TE, Younkin SG (1993) Release of excess amyloid beta protein from a mutant amyloid beta protein precursor. Science 259:514-516.

Calhoun ME, Burgermeister P, Phinney AL, Stalder M, Tolnay M, Wiederhold KH, Abramowski D, Sturchler-Pierrat C, Sommer B, Staufenbiel M, Jucker M (1999) Neuronal overexpression of mutant amyloid precursor protein results in prominent deposition of cerebrovascular amyloid. Proc Natl Acad Sci USA 96:14088-14093.

Cavalieri B (1966) Geometria degli indivisibili. Torino, Italy.

Citron M, Oltersdorf T, Haass C, McConlogue L, Hung AY, Seubert P, VigoPelfrey C, Lieberburg I, Selkoe DJ (1992) Mutation of the beta-amyloid precursor protein in familial Alzheimer's disease increases beta-protein production. Nature 360:672-674.

Citron M, Westaway D, Xia W, Carlson G, Diehl T, Levesque G, JohnsonWood K, Lee M, Seubert P, Davis A, Kholodenko D, Motter R, Sherrington R, Perry B, Yao H, Strome R, Lieberburg I, Rommens J, Kim S, Schenk D, et al. (1997) Mutant presenilins of Alzheimer's disease increase production of 42-residue amyloid beta-protein in both transfected cells and transgenic mice. Nat Med 3:67-72.

Corder EH, Saunders AM, Strittmatter WJ, Schmechel DE, Gaskell PC, Small GW, Roses AD, Haines JL, Pericak-Vance MA (1993) Gene dose of apolipoprotein E type 4 allele and the risk of Alzheimer's disease in late onset families. Science 261:921-923.

Davis J, Van Nostrand WE (1996) Enhanced pathologic properties of Dutch-type mutant amyloid beta-protein. Proc Natl Acad Sci USA 93:2996-3000.

DeMattos RB, Bales KR, Cummins DJ, Dodart JC, Paul SM, Holtzman DM (2001) Peripheral anti-A beta antibody alters CNS and plasma A beta clearance and decreases brain A beta burden in a mouse model of Alzheimer's disease. Proc Natl Acad Sci USA 98:8850-8855.

DeMattos RB, O’Dell MA, Parsadanian M, Taylor JW, Harmony JA, Bales KR, Paul SM, Aronow BJ, Holtzman DM (2002) Clusterin promotes amyloid plaque formation and is critical for neuritic toxicity in a mouse model of Alzheimer's disease. Proc Natl Acad Sci USA 99:10843-10848.

Eckman CB, Mehta ND, Crook R, Perez-tur J, Prihar G, Pfeiffer E, GraffRadford N, Hinder P, Yager D, Zenk B, Refolo LM, Prada CM, Younkin SG, Hutton M, Hardy J (1997) A new pathogenic mutation in the APP gene (I716V) increases the relative proportion of A beta 42(43). Hum Mol Genet 6:2087-2089.

Fagan AM, Watson M, Parsadanian M, Bales KR, Paul SM, Holtzman DM (2002) Human and murine ApoE markedly alter A beta metabolism before and after plaque formation in a mouse model of Alzheimer's disease. Neurobiol Dis 9:305-318.

Games D, Adams D, Alessandrini R, Barbour R, Berthelette P, Blackwell C, Carr T, Clemens J, Donaldson T, Gillespie F, et al (1995) Alzheimer-type neuropathology in transgenic mice overexpressing V717F beta-amyloid precursor protein. Nature 373:523-527.
Ghersi-Egea JF, Gorevic PD, Ghiso J, Frangione B, Patlak CS, Fenstermacher JD (1996) Fate of cerebrospinal fluid-borne amyloid beta-peptide: rapid clearance into blood and appreciable accumulation by cerebral arteries. J Neurochem 67:880-883.

Goate A, Chartier-Harlin MC, Mullan M, Brown J, Crawford F, Fidani L, Giuffra L, Haynes A, Irving N, James L, Mant R, Newton P, Rooke K, Roques P, Talbot C, Pericak-Vance M, Roses A, Williamson R, Rossor M, Owen M, et al. (1991) Segregation of a missense mutation in the amyloid precursor protein gene with familial Alzheimer's disease. Nature 349:704-706.

Gomori G (1936) Microtechnical demonstration of iron. Am J Pathol 12:655-663.

Grabowski TJ, Cho HS, Vonsattel JP, Rebeck GW, Greenberg SM (2001) Novel amyloid precursor protein mutation in an Iowa family with dementia and severe cerebral amyloid angiopathy. Ann Neurol 49:697-705.

Greenberg SM (1998) Cerebral amyloid angiopathy: prospects for clinical diagnosis and treatment. Neurology 51:690-694.

Greenberg SM (2002) Cerebral amyloid angiopathy and vessel dysfunction. Cerebrovasc Dis 13:42-47.

Greenberg SM, Rebeck GW, Vonsattel JP, Gomez-Isla T, Hyman BT (1995) Apolipoprotein E epsilon 4 and cerebral hemorrhage associated with amyloid angiopathy. Ann Neurol 38:254-259.

Greenberg SM, Briggs ME, Hyman BT, Kokoris GJ, Takis C, Kanter DS, Kase CS, Pessin MS (1996) Apolipoprotein E epsilon 4 is associated with the presence and earlier onset of hemorrhage in cerebral amyloid angiopathy. Stroke 27:1333-1337.

Greenberg SM, Vonsattel JP, Segal AZ, Chiu RI, Clatworthy AE, Liao A, Hyman BT, Rebeck GW (1998) Association of apolipoprotein E epsilon2 and vasculopathy in cerebral amyloid angiopathy. Neurology 50:961-965.

Haass C, Hung AY, Selkoe DJ, Teplow DB (1994) Mutations associated with a locus for familial Alzheimer's disease result in alternative processing of amyloid beta-protein precursor. J Biol Chem 269:17741-17748.

Hock Jr BJ, Lamb BT (2001) Transgenic mouse models of Alzheimer's disease. Trends Genet 17:S7-12.

Holtzman DM, Bales KR, Wu S, Bhat P, Parsadanian M, Fagan AM, Chang LK, Sun Y, Paul SM (1999) Expression of human apolipoprotein E reduces amyloid-beta deposition in a mouse model of Alzheimer's disease. J Clin Invest 103:R15-R21.

Holtzman DM, Fagan AM, Mackey B, Tenkova T, Sartorius L, Paul SM, Bales K, Ashe KH, Irizarry MC, Hyman BT (2000a) Apolipoprotein E facilitates neuritic and cerebrovascular plaque formation in an Alzheimer's disease model. Ann Neurol 47:739-747.

Holtzman DM, Bales KR, Tenkova T, Fagan AM, Parsadanian M, Sartorius LJ, Mackey B, Olney J, McKeel D, Wozniak D, Paul SM (2000b) Apolipoprotein $\mathrm{E}$ isoform-dependent amyloid deposition and neuritic degeneration in a mouse model of Alzheimer's disease. Proc Natl Acad Sci USA 97:2892-2897.

Hsiao K, Chapman P, Nilsen S, Eckman C, Harigaya Y, Younkin S, Yang F, Cole G (1996) Correlative memory deficits, Abeta elevation, and amyloid plaques in transgenic mice. Science 274:99-102.

Ji Y, Permanne B, Sigurdsson EM, Holtzman DM, Wisniewski T (2001) Amyloid beta40/42 clearance across the blood-brain barrier following intra-ventricular injections in wild-type, apoE knock-out and human apoE3 or E4 expressing transgenic mice. J Alzheimers Dis 3:23-30.

Joachim CL, Duffy LK, Morris JH, Selkoe DJ (1988) Protein chemical and immunocytochemical studies of meningovascular beta-amyloid protein in Alzheimer's disease and normal aging. Brain Res 474:100-111.

Johnson-Wood K, Lee M, Motter R, Hu K, Gordon G, Barbour R, Khan K, Gordon M, Tan H, Games D, Lieberburg I, Schenk D, Seubert P, McConlogue L (1997) Amyloid precursor protein processing and A beta42 deposition in a transgenic mouse model of Alzheimer disease. Proc Natl Acad Sci USA 94:1550-1555.

LaDu MJ, Falduto MT, Manelli AM, Reardon CA, Getz GS, Frail DE (1994) Isoform-specific binding of apolipoprotein $\mathrm{E}$ to beta-amyloid. J Biol Chem 269:23403-23406.

Lannfelt L, Bogdanovic N, Appelgren H, Axelman K, Lilius L, Hansson G, Schenk D, Hardy J, Winblad B (1994) Amyloid precursor protein mutation causes Alzheimer's disease in a Swedish family. Neurosci Lett 168:254-256.

Levy E, Carman MD, Fernandez-Madrid IJ, Power MD, Lieberburg I, van Duinen SG, Bots GT, Luyendijk W, Frangione B (1990) Mutation of the 
Alzheimer's disease amyloid gene in hereditary cerebral hemorrhage, Dutch type. Science 248:1124-1126.

McCarron MO, Nicoll JA, Stewart J, Cole GM, Yang F, Ironside JW, Mann DM, Love S, Graham DI (2000) Amyloid beta-protein length and cerebral amyloid angiopathy-related haemorrhage. NeuroReport 11:937-940.

Miravalle L, Tokuda T, Chiarle R, Giaccone G, Bugiani O, Tagliavini F, Frangione B, Ghiso J (2000) Substitutions at codon 22 of Alzheimer's abeta peptide induce diverse conformational changes and apoptotic effects in human cerebral endothelial cells. J Biol Chem 275:27110-27116.

Monro OR, Mackic JB, Yamada S, Segal MB, Ghiso J, Maurer C, Calero M, Frangione B, Zlokovic BV (2002) Substitution at codon 22 reduces clearance of Alzheimer's amyloid-beta peptide from the cerebrospinal fluid and prevents its transport from the central nervous system into blood. Neurobiol Aging 23:405-412.

Munson GW, Roher AE, Kuo YM, Gilligan SM, Reardon CA, Getz GS, LaDu MJ (2000) SDS-stable complex formation between native apolipoprotein E3 and beta-amyloid peptides. Biochemistry 39:16119-16124.

Murrell J, Farlow M, Ghetti B, Benson MD (1991) A mutation in the amyloid precursor protein associated with hereditary Alzheimer's disease. Science 254:97-99.

Naslund J, Thyberg J, Tjernberg LO, Wernstedt C, Karlstrom AR, Bogdanovic N, Gandy SE, Lannfelt L, Terenius L, Nordstedt C (1995) Characterization of stable complexes involving apolipoprotein $\mathrm{E}$ and the amyloid beta peptide in Alzheimer's disease brain. Neuron 15:219-228.

Nicoll JA, Burnett C, Love S, Graham DI, Ironside JW, Vinters HV (1996) High frequency of apolipoprotein E epsilon 2 in patients with cerebral hemorrhage due to cerebral amyloid angiopathy. Ann Neurol 39:682-683.

Nicoll JA, Burnett C, Love S, Graham DI, Dewar D, Ironside JW, Stewart J, Vinters HV (1997) High frequency of apolipoprotein E epsilon 2 allele in hemorrhage due to cerebral amyloid angiopathy. Ann Neurol 41:716-721.

Nilsberth C, Westlind-Danielsson A, Eckman CB, Condron MM, Axelman K, Forsell C, Stenh C, Luthman J, Teplow DB, Younkin SG, Naslund J, Lannfelt L (2001) The "Arctic" APP mutation (E693G) causes Alzheimer's disease by enhanced Abeta protofibril formation. Nat Neurosci 4:887-893.

Permanne B, Perez C, Soto C, Frangione B, Wisniewski T (1997) Detection of apolipoprotein E/dimeric soluble amyloid beta complexes in Alzheimer's disease brain supernatants. Biochem Biophys Res Commun 240:715-720.

Pfeifer M, Boncristiano S, Bondolfi L, Stalder A, Deller T, Staufenbiel M, Mathews PM, Jucker M (2002) Cerebral hemorrhage after passive antiAbeta immunotherapy. Science 298:1379.

Prelli F, Castano E, Glenner GG, Frangione B (1988) Differences between vascular and plaque core amyloid in Alzheimer's disease. J Neurochem 51:648-651.

Rebeck GW, Reiter JS, Strickland DK, Hyman BT (1993) Apolipoprotein E in sporadic Alzheimer's disease: allelic variation and receptor interactions. Neuron 11:575-580.

Revesz T, Holton JL, Lashley T, Plant G, Rostagno A, Ghiso J, Frangione B (2002) Sporadic and familial cerebral amyloid angiopathies. Brain Pathol 12:343-357.

Russo C, Angelini G, Dapino D, Piccini A, Piombo G, Schettini G, Chen S, Teller JK, Zaccheo D, Gambetti P, Tabaton M (1998) Opposite roles of apolipoprotein E in normal brains and in Alzheimer's disease. Proc Natl Acad Sci USA 95:15598-15602.

Schmechel DE, Saunders AM, Strittmatter WJ, Crain BJ, Hulette CM, Joo SH, Pericak-Vance MA, Goldgaber D, Roses AD (1993) Increased amyloid beta-peptide deposition in cerebral cortex as a consequence of apolipoprotein E genotype in late-onset Alzheimer disease. Proc Natl Acad Sci USA 90:9649-9653.
Shibata M, Yamada S, Kumar SR, Calero M, Bading J, Frangione B, Holtzman DM, Miller CA, Strickland DK, Ghiso J, Zlokovic BV (2000) Clearance of Alzheimer's amyloid-ss(1-40) peptide from brain by LDL receptorrelated protein-1 at the blood-brain barrier. J Clin Invest 106:1489-1499.

Strittmatter WJ, Bova Hill C (2002) Molecular biology of apolipoprotein E. Curr Opin Lipidol 13:119-123.

Strittmatter WJ, Roses AD (1995) Apolipoprotein E and Alzheimer disease. Proc Natl Acad Sci USA 92:4725-4727.

Strittmatter WJ, Saunders AM, Schmechel D, Pericak-Vance M, Enghild J, Salvesen GS, Roses AD (1993) Apolipoprotein E: high-avidity binding to beta-amyloid and increased frequency of type 4 allele in late-onset familial Alzheimer disease. Proc Natl Acad Sci USA 90:1977-1981.

Styren SD, Hamilton RL, Styren GC, Klunk WE (2000) X-34, a fluorescent derivative of Congo red: a novel histochemical stain for Alzheimer's disease pathology. J Histochem Cytochem 48:1223-1232.

Suzuki N, Iwatsubo T, Odaka A, Ishibashi Y, Kitada C, Ihara Y (1994) High tissue content of soluble beta 1-40 is linked to cerebral amyloid angiopathy. Am J Pathol 145:452-460.

Tagliavini F, Rossi G, Padovani A, Magoni M, Andora G, Sgarzi M, Bizzi A, Savoiardo M, Carella F, Morbin M, Giaccone G, Bugiani O (1999) A new APP mutation related to hereditary cerebral hemorrhage. Alzh Reports 2:S28.

Tanzi RE, Bertram L (2001) New frontiers in Alzheimer's disease genetics. Neuron 32:181-184.

Van Dorpe J, Smeijers L, Dewachter I, Nuyens D, Spittaels K, Van Den Haute C, Mercken M, Moechars D, Laenen I, Kuiperi C, Bruynseels K, Tesseur I, Loos R, Vanderstichele H, Checler F, Sciot R, Van Leuven F (2000) Prominent cerebral amyloid angiopathy in transgenic mice overexpressing the London mutant of human APP in neurons. Am J Pathol 157:1283-1298.

Van Nostrand WE, Melchor JP, Cho HS, Greenberg SM, Rebeck GW (2001) Pathogenic effects of D23N Iowa mutant amyloid beta-protein. J Biol Chem 276:32860-32866.

Vinters HV (1987) Cerebral amyloid angiopathy. A critical review. Stroke 18:311-324.

Weller RO, Massey A, Newman TA, Hutchings M, Kuo YM, Roher AE (1998) Cerebral amyloid angiopathy: amyloid beta accumulates in putative interstitial fluid drainage pathways in Alzheimer's disease. Am J Pathol 153:725-733.

Winkler DT, Bondolfi L, Herzig MC, Jann L, Calhoun ME, Wiederhold KH, Tolnay M, Staufenbiel M, Jucker M (2001) Spontaneous hemorrhagic stroke in a mouse model of cerebral amyloid angiopathy. J Neurosci 21:1619-1627.

Winkler DT, Biedermann L, Tolnay M, Allegrini PR, Staufenbiel M, Wiessner C, Jucker M (2002) Thrombolysis induces cerebral hemorrhage in a mouse model of cerebral amyloid angiopathy. Ann Neurol 51:790-793.

Wisniewski T, Golabek A, Matsubara E, Ghiso J, Frangione B (1993) Apolipoprotein E: binding to soluble Alzheimer's beta-amyloid. Biochem Biophys Res Commun 192:359-365.

Wisniewski T, Lalowski M, Golabek A, Vogel T, Frangione B (1995) Is Alzheimer's disease an apolipoprotein E amyloidosis? Lancet 345:956-958.

Wisniewski T, Ghiso J, Frangione B (1997) Biology of A beta amyloid in Alzheimer's disease. Neurobiol Dis 4:313-328.

Zlokovic BV, Mackic JB, Wang L, McComb JG, McDonough A (1993) Differential expression of $\mathrm{Na}$, K-ATPase alpha and beta subunit isoforms at the blood-brain barrier and the choroid plexus. J Biol Chem 268:8019-8025.

Zlokovic BV, Martel CL, Matsubara E, McComb JG, Zheng G, McCluskey RT, Frangione B, Ghiso J (1996) Glycoprotein 330/megalin: probable role in receptor-mediated transport of apolipoprotein $\mathrm{J}$ alone and in a complex with Alzheimer disease amyloid beta at the blood-brain and bloodcerebrospinal fluid barriers. Proc Natl Acad Sci USA 93:4229-4234. 